\title{
The Planning of Learning Model for Students with Hearing Impairments in the Elementary School Inclusion
}

\author{
Indina Tarjiah \\ State University Of Jakarta, Jakarta, Indonesia \\ e-mail: indina2009@yahoo.co.id / indina.tarjiah@gmail.com
}

\begin{abstract}
This research aims to produce a design of the model of planning learning for students with hearing impairments in inclusive elementary school in the region of DKI Jakarta. This research involves a number of subjects as participants i.e. academics, teachers in inclusive elementary schools, and teachers of the school outstanding. Research methods used in this research is quantitative research with engineering survey to obtain data about problems in learning for deaf learners to then be processed, analyzed which then serve as material for the development of model design planning of learning for students with hearing impairments at Elementary School Inclusion. The research was carried out in February until May 2016 at 10 State primary school inclusive education providers in the region of DKI Jakarta. The results showed that of the 10 schools, there are 7 schools have yet to develop a plan of learning and not to apply the principles of learning for the students with hearing impairments, while the 3 schools have already begun trying to adjust to the needs of deaf students, although not optimal. Based on the above findings, then design learning planning model designed for deaf students with the following stages: (1) the development of the syllabus. (2) the development of the plan of implementation of the Programme of learning and Individual Learning.
\end{abstract}

Keywords : $\quad$ School inclusion, planning of Learning Model, students are deaf.

\section{INTRODUCTION}

Children with hearing impairment require special education services in order to develop its potential optimally. Curriculum and the learning process needs to be designed specifically so that it fits with their needs, so that in turn is able to empower them to become an independent human. The Organization of special education for children with hearing impairment has been the commitment of the Government of Indonesia. This looks of sound article 5 paragraph 2 of ACT No. 20/2003 which States that citizens who have abnormalities of physical, emotional, mental, intellectual, social and/or eligible for special education.

The facts on the ground indicate that there is still very little deaf children and children in need of special education which has got a chance. Data sourced from the Central Bureau of statistics (BPS) said that the number of children in need of special projection in Indonesia in 2008 was 1,504,000 people, and 322 thousand of whom are school-age children in need special (5-18 yrs). Furthermore, the data of the Directorate of the school's Outstanding Coaching (PSLB) shows that the number of children in need has got special education in schools was 66,610 .

Thus, recently, about $20 \%$ of children in need of special school age (including the deaf) who has had the opportunity to follow education. His little access to education for deaf children and children in need special, because it's still the least amount of outstanding schools (SLB) in Indonesia. Data of the Ministry of national education mentioned that currently there were only recorded 1569 SLB across Indonesia from pre-school until secondary school. Of these only 302 schools run by the Government (public schools).

There are two fundamental issues which led to the sluggish development of outstanding school, namely (1) the establishment of the necessary investment costs SLB expensive, (2) on the other hand the existence of children in need of special is not concentrated in one area in great numbers, but it is scattered in various locations and corners. This condition causes the more economic establishment is not unusual.

To resolve the issue, currently there is one thought which is considered an effective inroads to tackling the problem of educational opportunities for deaf children, i.e. the concept of "inclusive 
education". Inclusive education can be meant as a philosophy and also strategy in education, where children with a variety of conditions (including children in need special) can be educated together in regular schools (public school). This thinking is promising an increase in educational opportunities that are significant for deaf students, because of the inclusive education opportunites to deaf students to attend regular school education (public schools) anywhere close to his residence.

Inclusive education have been rolled out by the Government. A number of regular school has been established as an inclusive education providers schools both public and private. In Jakarta for example, currently listed there are 372 designated as school schools inclusive education providers, which include primary school (elementary school), Middle School (Junior High School), a secondary school (High School) and secondary school (SMK). For the primary school level, there are approximately 200 schools inclusive education providers. The schools in addition to running his mission of giving education to the students of "General", they also receive and serve the education for the children in need special, including deaf students.

To date research review about optimalisasai education services leading to more inclusive aspect of the infrastructure supporting inclusive education services, understanding of educators and educational power against the objective of inclusive education in primary schools, the limited knowledge of parents and teachers about the concept of the children in need special and inclusive education concept.

Schools that expressed as inclusive schools generally don't have teachers who have the insight and ability to serve children in need of special. Also supporting facilities and infrastructure are not yet adequately equipped. Schools and teachers as well as other parties involved in education are still ambiguous about how inclusive education should be run. This relates to the issue of curriculum, learning, classroom setting and infrastructure, evaluation of learning, increase graduation class, and others. They do not yet have an adequate understanding, how such aspects should be designed so that it is suitable for deaf children.

Research related to development of a model of learning for the children in need special has been done by Supena (2010) about the development of inclusive education service for students mental retardation. Subsequent research conducted by Indina (2014) about the development model of learning for students learning difficulties in the elementary school inclusion. Meanwhile some research that examines about optimization of the inclusive education service has been done more leads on the infrastructure supporting the inclusive education services, understanding of educators and educational power against the objective of inclusive education in primary school, teachers of children in need special and inclusive education, inclusive education environment towards the development of a children in need special behavior (Indriawati, 2013; Mahabbati, 2010) Research (Elisha: 2013) about the inclusive education focuses on the role of teachers of special education supervisor, inclusive attitudes of educators, educational personnel, and attitude of the students towards the inclusive education.

The research concentrates on development model of learning is still very lacking, while children in need of special type consists of 9 species, one of which is a child with a hearing impairments or deaf. Based on the above studies show that current research on inclusive education examines many aspects of external supporters against holding of inclusive education. Therefore, to speed up the optimalisasai of learning for children in need of special education in inclusive settings, then the necessary research that leads to the development of one of the components of learning to one of the children in need special type that is associated with the planning of learning for deaf students in the elementary school inclusion.

\section{METHODS}

\subsection{Participants}

This research involves a number of subjects as participants i.e. academics, teachers at the school, the teacher in inclusive schools and also the bureaucracy associated with the implementation of the educational inclusion.

\subsection{Procedure}

This research begins with doing coordination with 10 elementary school inclusion for initial data capture in the field related to the analysis of the potential and problems, then from the results of surveys carried out discussions (FGD) data analysis and discussion of the model of learning in the design of the workshop model of learning. This activity involves experts in the field of Education (academics), special school teachers (SLB), regular school teachers and bureaucrats. 


\section{THE RESULTS OF THE RESEARCH AND THE DISCUSSION}

The syllabus is the learning plans are made for a period of one semester for a particular subject. The syllabus is made in the form of a matrix (table) which contains 8 components namely (1) the standard of competence, basic competence (2), (3) material formulation, (4) indicators of success, learning activities (5), (6) the allocation of time, (7) resources and media learning, (8) evaluation. The syllabus is created for each subject, in one semester in a class. In addition to loading the 8 components of the above, the syllabus is usually preceded by the identity of the subjects.

Learning implementation plan (RPP) is a learning plan that is made for one or several times within a particular subject. RPP is outlining more details and operation of the syllabus. Components written in more or less the same as the RPP syllabus. The difference with the syllabus is that the RPP is made not in the form of a matrix (a table) but the blurb that extends to the bottom.

\section{EXAMPLE FORMAT FOR HEARING IMPAIRMENT STUDENTS LEARNING SYLLABUS IN INCLUSIVE SCHOOLS}

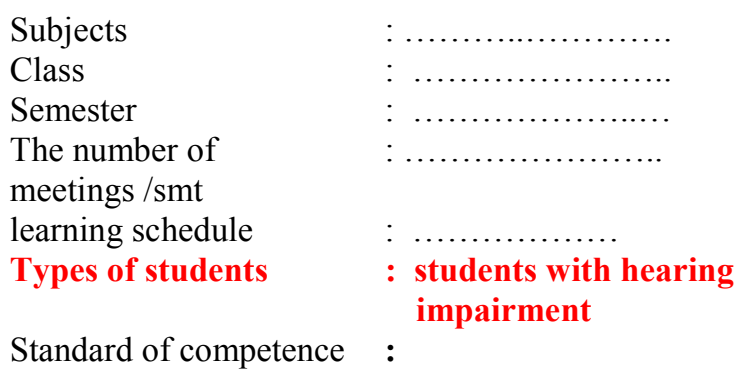

\begin{tabular}{|l|l|l|c|c|c|c|}
\hline $\begin{array}{l}\mathrm{K} \\
\mathrm{D}\end{array}$ & $\begin{array}{c}\text { Ma } \\
\text { teri }\end{array}$ & $\begin{array}{c}\text { Indika } \\
\text { tor }\end{array}$ & $\begin{array}{c}\text { Kegia } \\
\mathrm{t} \\
\text { an } \\
\text { pemb } \\
\text { elajar } \\
\text { an }\end{array}$ & $\begin{array}{c}\text { Alok } \\
\text { asi } \\
\text { wakt } \\
\mathrm{u}\end{array}$ & $\begin{array}{c}\text { Sum } \\
\text { ber } \\
\text { dan } \\
\text { medi } \\
\mathrm{a}\end{array}$ & $\begin{array}{c}\text { Eval } \\
\text { uasi }\end{array}$ \\
\hline $\begin{array}{l}\mathrm{U} \\
\mathrm{mu} \\
\mathrm{m}\end{array}$ & $\begin{array}{l}\mathrm{Um} \\
\mathrm{um}\end{array}$ & $\begin{array}{l}\mathrm{Umu} \\
\mathrm{m}\end{array}$ & $\begin{array}{c}\text { Modi } \\
\text { fikasi }\end{array}$ & $\begin{array}{l}\text { umu } \\
\mathrm{m}\end{array}$ & $\begin{array}{c}\text { Modi } \\
\text { fikasi }\end{array}$ & $\begin{array}{l}\text { Ada } \\
\text { beber } \\
\text { apa } \\
\text { modi } \\
\text { fikasi }\end{array}$ \\
\hline
\end{tabular}

The development of Learning Plans or RPP for deaf students in the inclusive school is basically the same as the procedures or steps in the development of the syllabus. The difference is that the RPP is made for one or more meetings. Blurb in the RPP also more detail than the syllabus, and hence the format of the RPP made lengthwise down not in the form of a matrix or table. The following are presented examples of common formats making syllabus for deaf in the inclusive school:

\section{AN EXAMPLE OF THE FORMAT OF THE PLAN OF IMPLEMENTATION OF THE LEARNING (RPP) TO DEAF/HEARING IMPAIRMENT STUDENTS IN INCLUSIVE SCHOOLS}

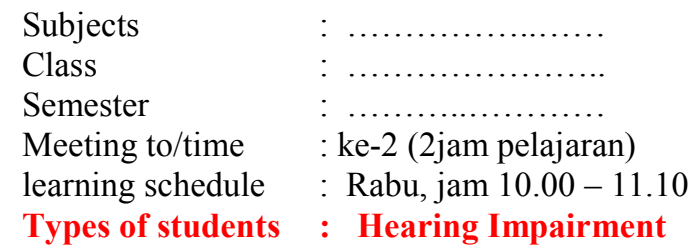

On the development of the RPP for deaf students; Standards of competence (not modified). Basic competence (not modified). Subject matter (not modified). Indicators of success (not modified). Allocation of time (not modified). Learning activities (no modification). Media and learning resources (there are some parts of the modification). Evaluation (there are some sections which are modified)

There are two models of the format of the implementation plan for inclusive learning-learning for the children in need special (1) Learning model of the implementation plan (RPP), (2) integrated model of separate Learning implementation plan, with the following description: a). Learning implementation planterintegrasi. Model integration is model of development of the implementation plan (RPP) Learning for students with hearing impairment that is integrated (merged) and implementation plan (RPP) for the learning of other students. Thus, in this model the teacher has only one RPP RPP, namely General, but inside it contains a special entry for deaf students learning. Special note-writing can be done in two ways, namely (1) special note made on each component of the RPP who underwent modifications (content, learning activities, indicators, media, evaluation) (2) special note made public at the end of the RPP. See the example in the Appendix. b). RPP separate (Individual). Individual is a model plan RPP learning that is made specifically for students with 
hearing impairment, meaning that apart from RPP to other students (regular). RPP this model fully contains planning teaching for deaf students and are individually. In addition to serving as RPP 8 components in General, individual RPP has 2 additional components namely (1) the identity of the student and (2) the ability of the students at this time. Because students with hearing impairments generally do not experience barriers to smarts and because most of the components of the RPP for the students with hearing impairment is the same with other students, then the format of the RPP that may be suitable for deaf school inclusive integrated RPP format is, however, did not close the possibility that teachers develop an individual RPP because of the condition of students demanding like that. The following public contofhformat the RPP is presented individually.

\section{AN EXAMPLE OF THE FORMAT OF THE PLAN OF IMPLEMENTATION OF THE LEARNING (RPP) TO DEAF STUDENTS IN INCLUSIVE SCHOOLS (SEPARATE/INDIVIDUAL MODELS)}

Subjects
Class/semester
Meeting
Time

The Identity of The Students

Name of student

Gender

Date of birth

Age

Types of barriers

the level of resistance

The address of the

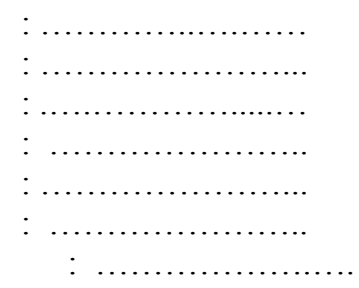

The ability of the students currently:

On the development model of separate/individual RPP; Standards of competence (not modified), the basic Competence (not modified), subject matter (not modified), indicators of success (not modified), the allocation of time (not modified), the Learning Activities (there are mods), Media and learning resources (there are mods), and evaluation (relative contents are the same, there are some parts of the modified)
Learning resources (material)

Learning resources is everything that can be used as a source for acquiring knowledge, skills and/or experience for students. Source (material) a written learning for deaf students are essentially the same as other students. This means that the text books and other written materials that can be used by other students (General), essentially can also be used by deaf students. Just need a little help or guidance from teachers, particularly for the ability of deaf language has not developed enough. This condition usually occurs in primary level.

Therefore, when students with hearing impairments try to read the textbooks of general lessons, then consider and ask if they can understand the contents of the book. If not, then give additional explanation and if necessary use a picture, a photo, a demonstration, or the media to explain it. If possible, teachers create learning resources (textbooks lessons) in its own specifically for deaf students, by way of modifying the General textbook. But this may be more appropriately done by the teacher supervising special or teachers who are already commonplace (experienced) teaching students with hearing impairments. Use wherever possible learning resource that can provide concrete and directly experience for deaf students, for example, school gardens, a Zoo, a visit to puskesman, the police station, museums, fields, forests, markets, and others. This will reduce the possibility of wrong concept or the usual concept of poor experienced by students with hearing impairments. It is also important for the development of language in students with hearing impairments/hearing impairments.

\section{CONCLUSIONS}

Planning learning preparation is made in writing by the teacher before executing the instruction. There are two main types of learning plans created by teachers, namely (1) the syllabus, and (2) the plan of implementation of the learning/RPP. Develop the student's learning syllabus for hearing impairments in the inclusive school is noticed on the following aspects: a). Format and syllabus component equal to a common syllabus. b identity/titles) on the syllabus, added information about the types of students in need of deaf students that is special. $\mathrm{c}$ the standard Formula of competence) (SK), Basic Competencies (KD), content, indicators and time allocation unchanged. Learning Activity d). There are modifications. e). 
Sources and media of instruction, there are mods, disesuaikandengan condition of the deaf. f) allocation of time almost no modifications (changes) with regard to the allocation of time learning. g) evaluation. In General, the evaluation questions that were imposed to the deaf students are generally the same as those given to other students. But maybe there will be modifications in most materials, the means, and the tools used in the evaluation. There are two models the format of Learning implementation plan (RPP) to inclusive learning for the children in need special, namely (1) the model integrated RPP, (2) model RPP apart, with the following description: a). RPP is integrated.

\section{REFERENCES}

[1] Anita Woolfolk (2004). Educational Psychology (ninth edition, International edition). Boston: Pearson education, Inc.

[2] Asep Supena, dkk (2012) Pendidikan Anak Berkebutuhan Khusus. Jakarta: 28 Jaya Printing \& Publisher

[3] Asep Supena (2010) Model Layanan Pendidika bagi Siswa Tunagrahita di Sekolah Dasar Inklusi. Lemlit UNJ

[4] Cullata, Tompkins, Werts (2003). Fundamentals of Special Education (second edition). New Jersey: Merrill Prentice Hall.

[5] Departemen Pendidikan Nasional (2007). Statistik Persekolah PLB 2006/2007. Jakarta: Pusat Statistik Pendidikan, badan Penelitian dan Pengembangan, Depdinas.

[6] Friend, Marilyn (2005). Special Education: Contemporary Perspectives for School Professionals. New York: Pearson Education Inc.

[7] Gargiulo, Richard, M. (2006). Special Education in Contemporary Society.USA: Thomson Wadsworth.

[8] Indina Tarjiah dan Asep Supena (2015). Pembelajaran Bagi Anak Berbakat Akademik. Jakarta: LPP Press UNJ.

[9] Indina Tarjiah dan Asep Supena (2014) Pengembangan Model Pembelajaran bagi Anak Berkesulitan Belajar di Sekolah Dasar Inklusi DKI Jakarta. Lemlit UNJ

[10] Indriawati, P. (2013) Implementasi Kebijakan Tugas Guru Pembimbing Khusus pada Pendidikan Inklusif di SD Negeri se Kecamatan Junrejo Batu, 1, 49-54.

[11] Mahabbati, A. (2010) Pendidikan Inklusif untuk Anak dengan Gangguan Emosi dan
Perilaku (Tunalaras).778-2620-2-PB. Pdf Jurnal Pendidikan khusus, 7 (2), 52-63

[12] Pouwer, Jan (1974).The Structural Configurational Approach a Methodilogical Outline. New York: Dutton \& Co.

[13] J. David Sminth (2006). Inklusi, sekolah ramah untuk semua (editor ahli M.Sugiarmin dan MIF baihaqi). Bnadung: penerbit Nuansa.

[14] Paul Eggen and Don Kauchak (2004). Educational Psychology: Windows on Classrooms (sixth edition, international edition). New Jersey: Pearson Prentice Hall.

[15] Sugiyono (2006). Metode Penelitian Pendidikan: Pendekatan kuantitatif, Kualitatif dan $R \& D$. Bandung: Penerbit Alfabet.

[16] Tumbull, R., Turnbull, A., Shank, M., Smith, S.J. (2004). Exceptional Lives: Special Education in Today's School. New Jersey: Pearson Prentice Hall.

[17] Yusufhadi Miarso. (2004) Menyemai Benih Teknologi Pendidikan. Jakarta, Prenada Media.

[18] Yusufhadi Miarso. (1988). Survei Model Pengembangan Instruksional. Laporan Penelitian, Departemen Pendidikan dan Kebudayaan Dirjen Dikti. 